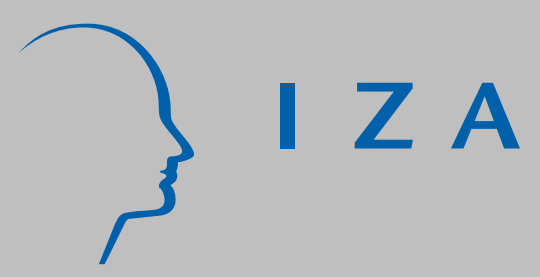

IZA DP No. 705

School Quality and Family Background in Italy

Giorgio Brunello

Daniele Checchi

J anuary 2003 


\title{
School Quality and Family Background in Italy
}

\author{
Giorgio Brunello \\ University of Padua, CESifo \\ and IZA Bonn
}

Daniele Checchi

University of Milan

\author{
Discussion Paper No. 705 \\ January 2003
}

\author{
IZA \\ P.O. Box 7240 \\ D-53072 Bonn \\ Germany \\ Tel.: +49-228-3894-0 \\ Fax: +49-228-3894-210 \\ Email: iza@iza.org
}

This Discussion Paper is issued within the framework of IZA's research area Internationalization of Labor Markets. Any opinions expressed here are those of the author(s) and not those of the institute. Research disseminated by IZA may include views on policy, but the institute itself takes no institutional policy positions.

The Institute for the Study of Labor (IZA) in Bonn is a local and virtual international research center and a place of communication between science, politics and business. IZA is an independent, nonprofit limited liability company (Gesellschaft mit beschränkter Haftung) supported by the Deutsche Post AG. The center is associated with the University of Bonn and offers a stimulating research environment through its research networks, research support, and visitors and doctoral programs. IZA engages in (i) original and internationally competitive research in all fields of labor economics, (ii) development of policy concepts, and (iii) dissemination of research results and concepts to the interested public. The current research program deals with (1) mobility and flexibility of labor, (2) internationalization of labor markets, (3) welfare state and labor market, (4) labor markets in transition countries, (5) the future of labor, (6) evaluation of labor market policies and projects and (7) general labor economics.

IZA Discussion Papers often represent preliminary work and are circulated to encourage discussion. Citation of such a paper should account for its provisional character. A revised version may be available on the IZA website (www.iza.org) or directly from the author. 
IZA Discussion Paper No. 705

January 2003

\section{ABSTRACT \\ School Quality and Family Background in Italy*}

We study whether the combined significant reduction in the pupil-teacher ratio and increase in parental education observed in Italy between the end of World War II and the end of the 1980s have had a significant impact on the educational attainment and the labor market returns of a representative sample of Italians born between 1941 and 1970 . We find that the lower pupil-teacher ratio is positively correlated with higher educational attainment, but that the overall improvement of parental education has had an even stronger impact on attainment. We also find that the positive impact of better school quality on educational attainment and returns to education has been particularly significant for the individuals born in regions and cohorts with poorer family background. Parental education has had asymmetric effects, positive on attainment and negative on school returns. Better school quality has also had asymmetric effects on the returns to education, positive for individuals with poor family background and negative for individuals born in regions and cohorts with relatively high parental education. Our evidence suggests that better school quality, measured by a lower pupil-teacher ratio, is a technical substitute to parental education in the production of individual human capital. When school quality and family background are substitutes, an increase of public resources invested in education can be used to reduce the differences induced by parental education.

JEL Classification: J24, J31

Keywords: education, quality, Italy

Corresponding author:

Giorgio Brunello

Department of Economics

University of Padova

Via del Santo 33

35100 Padova

Italy

Tel.: +39498274223

Fax: +3949827 4211

Email: brunello@decon.unipd.it

\footnotetext{
* Previous versions of this paper were presented at seminars in Bologna, Modena, Rome (Bank of Italy) and Salerno (AIEL). We are grateful to Simona Comi for efficient research assistance. The usual disclaimer applies.
} 


\section{Introduction}

There is a substantial literature that investigates the effects of indicators of school quality, such as class size and the pupil - teacher ratio, on test scores, educational attainment and the returns to education (see Hanushek [1986] [2002] and Card and Krueger [1996] for surveys of this literature). Most of this literature focuses on the U.S., but an increasing number of studies looks at different countries $^{1}$ and considers a comparative perspective ${ }^{2}$.

In spite of the large numbers of contributes in the area, there is no broad consensus on the economic effects of school quality. While there is agreement that better school quality improves educational attainment, the jury is still out on whether variations in class size affect significantly performance tests and the returns to education.

In modern societies, another factor with the potential of affecting both educational attainment and school returns is family background. Ermisch and Francesconi [2001] find that parents' educational attainments are very powerful predictors of their children's attainment. Sacerdote [2002] finds that being raised in a family with high socio-economic status greatly increases the probability that a child will attend college ${ }^{3}$. An important but somewhat overlooked question is how school quality and family background interact in the production of individual human capital. If they are technical substitutes, an improvement in school quality reduces the marginal contribution of family background to human capital, and therefore has the potential of reducing the differences induced by nurture. These differences widen when school quality and family background are technical complements. This paper considers this question, and investigates the relative contributions of family background and school quality to educational attainment and labor market performance in Italy.

The Italian institutional context is interesting but little explored. Primary and secondary education in this country is mostly public, virtually free, designed and organized centrally. Educational attainment is low by international standards (see OECD [2002]) but has increased significantly among the more recent cohorts. While the private returns to education are close to the European average (see Brunello, Lucifora and Comi [2001]), the performance of Italian students in international cognitive tests is rather disappointing (see the PISA results in OECD [2002]).

Despite the centralization of school design, school quality in Italy has exhibited important variations both over time and across different areas of the country. Figure 1 shows the average pupil teacher ratio in primary, lower secondary and upper secondary schools for 10 regions and three different age cohorts: compared to the cohort born between 1941 and 1945, the average pupil - teacher

\footnotetext{
${ }^{1}$ See for instance Dolton and Vignoles [1998], Wright [1999], Dearden, Ferri and Meghir [2000], Harmon and Walker [2000], Dustman, Rajah and van Soest [2002].

2 See Wossman [2000] and Guldlach et al [2001].

${ }^{3}$ See also Betts [1996], Dustmann [2001] and Behrman et al [1999].
} 
ratio experienced by the cohort born between 1966 and 1970 was almost half as high.

Figure 1 - Pupil - teacher ratio by age cohort and region of birth different school levels and average across school levels
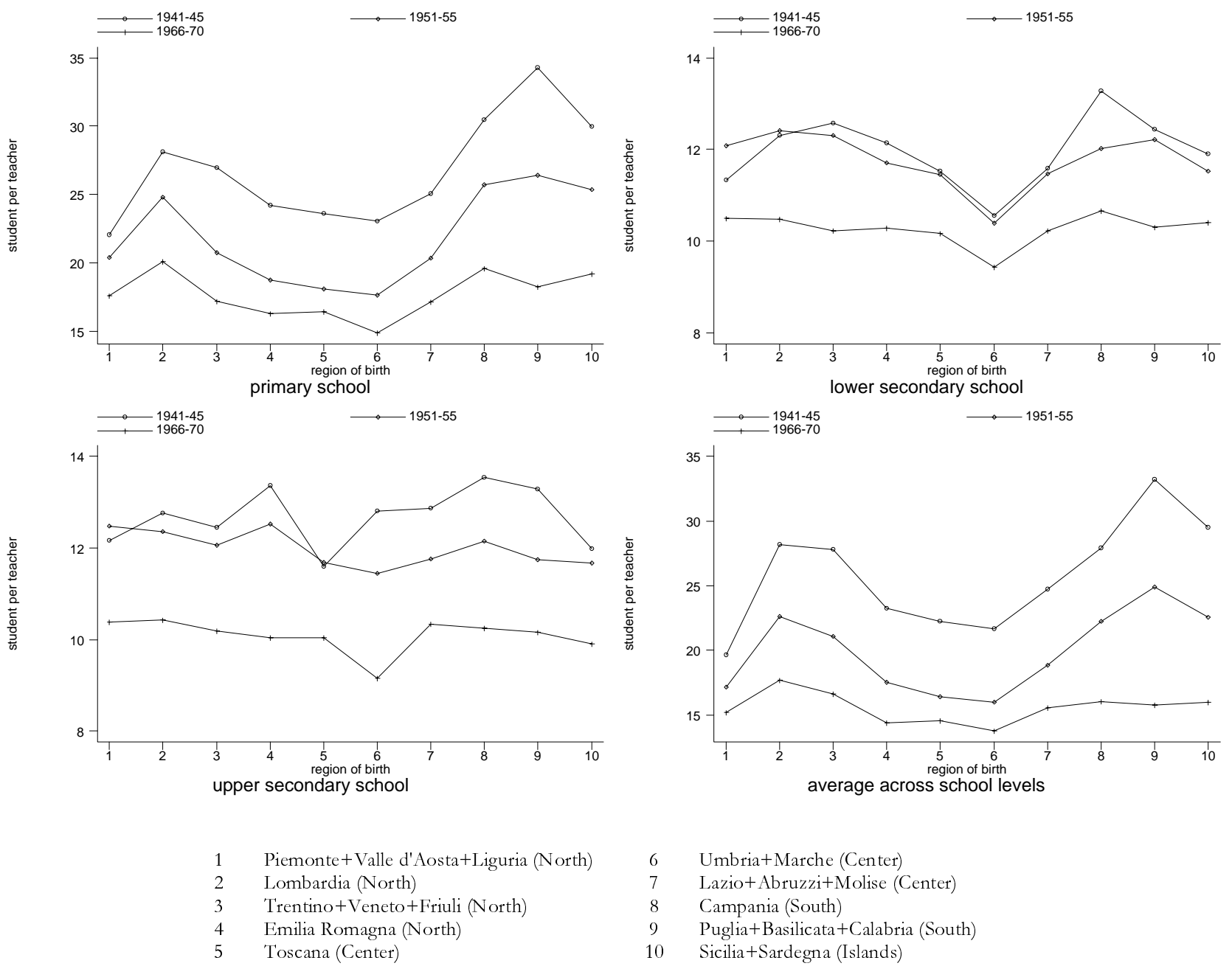

Umbria+Marche (Center)

Lazio+Abruzzi+Molise (Center)

Compared to the U.S., Italian society is less mobile, in terms both of educational attainment and of occupational outcomes. In Italy, less than 2 percent of the offspring of households where the father has not completed compulsory education has attained a college degree. In the US this percentage is close to 12 percent. Similarly, only 4 percent of Italians born in households where the father's income belongs to the lowest quartile of the income distribution receives college education, compared to 17 percent in the US (see Checchi, Ichino and Rustichini [1999]). When family background plays an important role in the education and labor markets, it can generate persistence of social and economic stratification. In this environment, (public) school quality, decided and administered by the central government, can have a countervailing effect and increase the social and economic opportunities of the children of less fortunate households. 
Gauging the relative importance of school quality and family background for educational attainment and labor market returns is important also because of the policy implications (see Hanushek [2002]). To illustrate, suppose that family background, measured by the educational attainment of parents, matters more than school quality in the production of individual human capital. Then policies that improve parental education, such as remedial adult schooling, continuous education and training, could be more effective than policies which reduce the number of pupils per class. ${ }^{4}$

The paper is organized as follows. Section 2 illustrates the empirical methodology, Section 3 presents the data, Section 4 shows the key results and Section 5 draws the main implications and concludes.

\section{Methodology and data}

Our investigation of whether changes in school quality, measured by the pupil - teacher ratio, and in family background, measured by the educational attainment of parents, affect educational attainment and the monetary returns to education follows the empirical approach taken by Card and Krueger [1992], Heckman et al [1997] and Strayer [2002]. An important part of the literature in this field (see Betts [1996] and Hanushek [2002] for reviews) uses school - specific measures of quality, which are not available in Italy. We use instead more aggregate measures, which vary with the region and the cohort of birth. On the one hand, the use of these measures leads to a systematic upward bias in the estimated effects of school quality. On the other hand, it reduces the measurement error bias associated to school - specific indicators (see Card and Krueger [1996]).

To estimate the impact of family background and school quality on the returns to education, we use a two - steps model. In the first step we perform the following regression

$$
Y_{i c r s}=\alpha_{c r s}+\beta X_{i c r s}+\gamma_{c r s} E_{i c r s}+\varepsilon_{i c r s}
$$

where $i$ is the individual, $c$ the age cohort, $r$ the region of birth and $s$ the region of residence, $Y$ is $\log$ annual earnings, $\alpha_{c r s}$ are region of birth by age cohort by region of residence dummies, $X$ is a vector of individual controls, $E$ is years of education and $\gamma$ measures the returns to education, which

\footnotetext{
${ }^{4}$ Changing parental education in the short run may be very costly. However, “..long run policy may.... reasonably relate to family factors. For example, arguments for improving women's education in developing countries may reflect the potential impact of children's achievement more than normal arguments about the return to the mother of human capital investment...(Hanushek [2002], p.39). Blöndal, Field and Girouard 2002 measure the returns to adult education and discuss policies to stimulate its acquisition.
} 
we allow to vary by cohort, region of birth and region of residence. In the second step we retrieve the estimated values of $\gamma$ and estimate

$$
\gamma_{c r s}=\lambda_{c}+\lambda_{r}+\lambda_{s}+\lambda_{c s}+\lambda_{r s}+\phi Q_{c r}+\psi W_{c r}+\sigma Q_{c r} W_{c r}+\varepsilon_{c r}
$$

where $\lambda$ are country, region of birth, region of residence, cohort $x$ region of residence and region $\times$ birth $\times$ region of residence dummies, $Q$ is school quality, which varies by region of birth and age cohort and $W$ is family background, which also varies by region of birth and age cohort. We define $W$ as the highest number of years of education attained by parents in the household. Therefore, if the mother has only primary education (5 years) and the father has completed junior high school (8 years) the value of $W$ for this household is 8 years. The value of $W$ for the region and the cohort of birth is obtained by averaging over households.

The region of residence dummies in [2] capture the effect of local labor markets on the returns to education. These effects can vary with the age cohort. The interaction of the dummies for the region of birth and the region of residence accounts for the effects of endogenous migration across regions (see Heckman et al [1997]). Variations in school quality and in family background capture the variability in the returns to education associated to the region and the cohort of birth. Finally, the interaction between $Q$ and $W$ is informative of whether these two factors are technical complements or substitutes in the production of human capital ${ }^{5}$.

Since educational attainment is measured as years of completed education, we use the following ordered probit model

$$
E_{i c r s}=\Phi\left(\delta Z_{i c r s}\right)
$$

where $Z$ is a vector of individual characteristics, including individual family background. A restriction imposed on [1]-[3] is that individual earnings are affected directly by average family background in the region and cohort of birth and indirectly by individual family background via its effects on educational attainment. By so doing, we follow Strayer [2002], who uses a similar exclusion restriction. Since educational attainment in [1] is the result of individual choice, we control for the selection bias by

\footnotetext{
${ }^{5}$ See the Appendix at the end of the paper.
} 
including in [1] the predicted score from the ordered probit model [3] (see Vella and Gregory [1996])

\section{The Data}

The data on individual annual earnings and educational attainment are drawn from the Survey on the Income and Wealth of Italian Households (SHIW), waves 1993, 1995, 1998 and 2000. Previous waves cannot be used because they lack information on family background. We consider only employees born between 1941 and 1970 who have a positive labor income and use the labor tax code to compute for each individual gross earnings from the original data on net earnings. We use annual rather than hourly earnings. There are two reasons for this. First, school quality and family background could also affect working hours; second, the available information is on weekly hours, which can be transformed into annual hours only by introducing an additional measurement error. In order to have a sufficient number of observations in each cell identified by the region of birth, the region of residence and the cohort of birth, we organize our sample into 6 age cohorts, each comprising five years, and aggregate the 20 regions of birth in the original data into 10 regions and the 20 regions of residence into 3 macro areas (North, Center and South).

In Italy there are no data on school quality at the school level that cover a nationally representative sample. Therefore, we follow Card and Krueger [1992] and use aggregate measures of quality based on the region and the cohort of birth. This choice is driven by the fact that, due to privacy restrictions, the SHIW survey makes available to researchers only the information on the region of birth. We collect regional data on the pupil - teacher ratio for different types of schools, ranging from kindergarten to upper secondary education, every two years from 1944 to 1989. In 1944 the oldest cohort born between 1941 and 1945 was eligible to start kindergarten and in 1989 the youngest cohort born between 1966 and 1970 could have completed upper secondary education ${ }^{7}$.

The key assumption is that most individuals complete their schooling, from less than primary to upper secondary, in their region of birth. The plausibility of assigning to each individual the school quality of the region of birth could obviously be questioned. In the absence of individual information on the age when migration between regions eventually took place, we present in Tables A.1 and A.2

\footnotetext{
${ }^{6}{ }_{6}$ With only two threshold levels, $a_{1}$ and $a_{2}$, the score is equal to $\frac{-\varphi\left(a_{1}-x b\right)}{\Phi\left(a_{1}-x b\right)}$ if $y<a_{1}$, $\frac{\varphi\left(a_{1}-x b\right)-\varphi\left(a_{2}-x b\right)}{\Phi\left(a_{1}-x b\right)-\Phi\left(a_{2}-x b\right)}$ if $a_{1}<y<a_{2}$ and $\frac{\varphi\left(a_{2}-x b\right)}{\Phi\left(a_{2}-x b\right)}$ if $y>a_{2}$, where $\varphi$ is the density function, $\Phi$ is the cumulative distribution function, $x b$ is the linear prediction and $y$ is the dependent variable in an ordered probit model. ${ }^{7}$ We collect data every other year because of the limited short-term variability in the data. We exclude college education because the assumption that this type of education is completed mainly in the region of birth is not tenable in Italy.
} 
information on the percentage of individuals who live in the same region of birth ${ }^{8}$. Internal migration is very low among the young, with less than $5 \%$ of individuals younger than 21 living in a region different from the region of birth. Turning to older individuals, who were born between 1941 and 1970, there is evidence of short - distance migration in the more developed Northern regions and of long distance migration from the poorest areas of South to the more developed North. Assuming that the observed pattern of migration experienced by the young has not changed significantly over time, the evidence in the two tables suggests a tendency for migration to take place mainly after completing up to upper secondary education in the region of birth.

In principle, we could match school quality to individuals in the sample by attributing to each individual the pupil - teacher ratio in the region of birth during the period when she went to school. To illustrate, an individual born in 1945 who went to kindergarten between 1948 and 1951, to primary school between 1951 and 1956, to junior high school between 1956 and 1958 and to upper secondary school between 1958 and 1963 is assigned the pupil - teacher ratio associated to each type of school in the same sub-period. This matching can be performed because we know the highest educational level attained by each individual.

It is questionable, however, to associate to each individual only the school quality of the schools he/she graduated from. Consider for instance the choice of continuing education after junior high school. This choice is likely to be affected by the expected quality of upper secondary education, despite the fact that the individual could end up not enrolling. Moreover, we only have information on attained degrees and cannot rule out the possibility that an individual enrolls in a school level and is exposed to the associated school quality without completing the degree.

These two arguments suggest that we should match each individual with the average school quality over the entire spectrum of school types, from kindergarten to upper secondary education. We compute average school quality by using enrolment rates during the relevant periods as weights. Table A.3 in the Data Appendix provides further details on the matching of data.

Figure 2 shows for the individuals born between 1941 and 1970 the dynamics of the average pupil - teacher ratio and of its regional dispersion by school type, where dispersion is measured by one standard deviation around the mean. The average pupil - teacher has declined sharply, from 26.23 for the cohort born between 1941 and 1945 to 15.35 for the cohort born between 1966 and 1970. The regional dispersion has also declined, and the coefficient of variation has fallen from 0.183 to 0.086 .

$884.4 \%$ of the individuals in our sample resides in the region of birth. This percentage is $80.9 \%$ for the oldest cohort and $90.1 \%$ for the youngest cohort. 
The reduction in the pupil - teacher ratio has involved all types of schools but has been sharpest for primary education?

This drastic decline contrasts with the significant increase in the educational attainment of individuals born during the same period, shown in Figure 3. Average educational attainment, measured as the number of years of attained education ${ }^{10}$, was equal to 8.23 years for the oldest cohort and to 11.26 years for the youngest cohort. The regional dispersion in educational attainment has also declined over time, and the coefficient of variation has fallen from 0.515 to 0.297.

Figure 2 - Pupil - teacher ratio by year of birth - different school levels
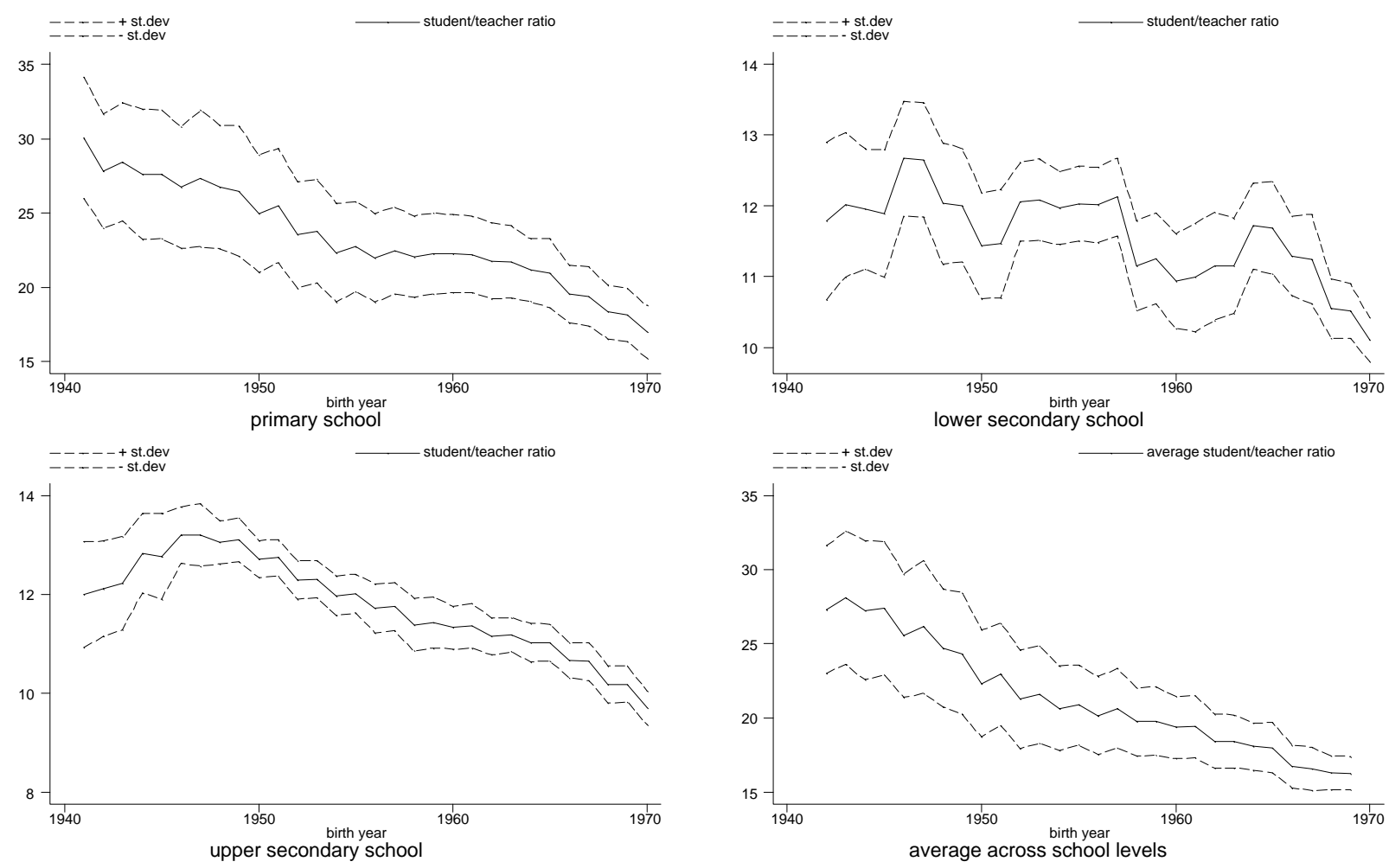

student/teacher ratio

\footnotetext{
${ }^{9}$ Further declines in the pupil - teacher ratio in primary schools took place after 1985, when a sweeping reform was introduced with the main purpose of maintaining employment levels among teachers in an environment characterized by a steady decline in the number of pupils.

${ }_{10}$ We assign 5 years to primary school, 8 years for junior high school, 11 or 13 years for secondary school, depending on the type of school, 15 or 18 years for college, depending on the type of college.
} 
Figure 3 - Educational attainment in the population by year of birth and school type
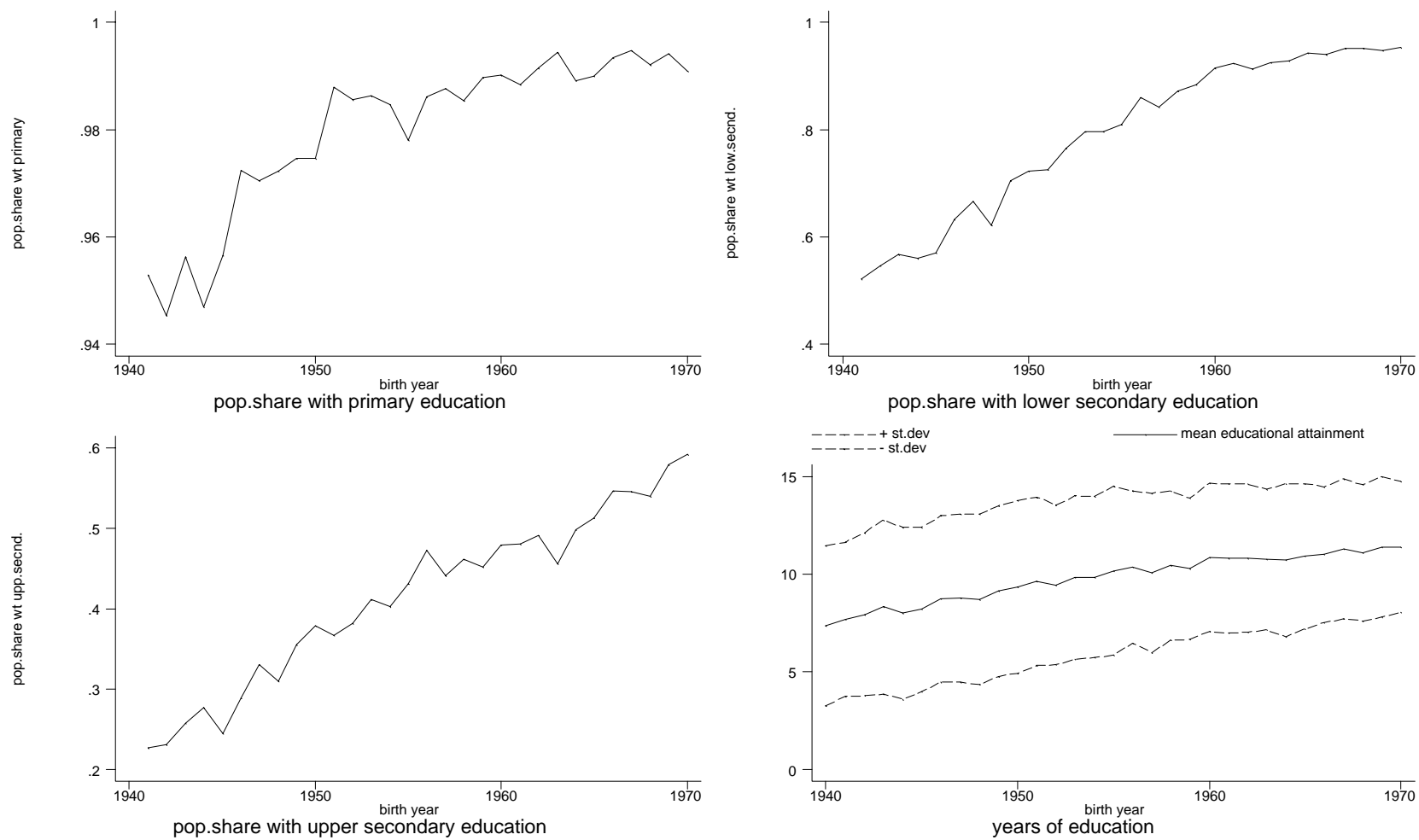

educational attainments in the population

We conclude the description of the data with our selected measure of family background $W$. As described above, this measure is the maximum number of years of education attained by parents within the household ${ }^{11}$. The average value of $W$ in the sample has increased from the 5.29 years (standard deviation: 2.286) of the oldest age cohort to the 7.38 (2.304) of the youngest cohort. As in the case of the educational attainment of the offspring, the regional dispersion in the attainment of parents has declined over the years, from 0.432 to 0.312 . The summary statistics of the main variables used in the paper are reported in Table A.4 in the Data Appendix.

\section{The Results}

We start the description of our empirical results with educational attainment. We regress individual attainment, measured in years, on individual family background, cohort, year, region of birth and region of residence dummies, a gender dummy and the pupil - teacher ratio. The first two columns in Table 1 report the estimates based on an ordered probit specification and the remaining columns

\footnotetext{
11 Our empirical results are not affected in a significant way if we use separately the educational attainment of the mother and of the father.
} 
show the results based on ordinary least squares. The latter estimates are included because the marginal effects in the case of an ordered probit cannot be signed in an unambiguous way (see Greene [1990]) ${ }^{12}$.

The regressions also include the interaction between family background $W$ and school quality $Q$. To reduce the collinearity between $W$ and the interaction between $W$ and $Q$, we define a new variable, $P$, as the percentage of households in the region and cohort of birth with at most primary education, and interact $P$ with $Q$. Since $Q$ and $P$ are more aggregated than individual information on attainment, we adjust standard errors for the lack of independence within clusters, with each cluster defined by the region of birth and age cohort.

Focusing on the ordered probit estimates, we find that educational attainment is higher when the pupil - teacher ratio is lower (so that school quality increases) and family background is better. When we introduce the interaction between school quality and family background, we find that it attracts a negative and significant coefficient, while school quality retains its sign but its coefficient is not any longer significantly different from zero. We interpret this as evidence that the impact of the pupil - teacher ratio on individual attainment varies with family background and is stronger when parental education in the region and cohort of birth is relatively low ( $P$ is higher). These findings are confirmed when we estimate the same model by ordinary least squares.

Table 1. Educational attainment. Ordered probit and OLS estimates

\begin{tabular}{|c|c|c|c|c|}
\hline $\begin{array}{l}\# \text { obs : } \\
\text { Depvar: } \\
\text { Method: }\end{array}$ & $\begin{array}{l}32991 \\
\text { E } \\
\text { oprobit }\end{array}$ & $\begin{array}{l}32991 \\
\text { E } \\
\text { oprobit }\end{array}$ & $\begin{array}{c}32991 \\
E \\
\text { ols }\end{array}$ & $\begin{array}{c}32991 \\
E \\
\text { ols }\end{array}$ \\
\hline $\begin{array}{l}\text { pupil - teacher } \\
\text { ratio } Q\end{array}$ & $\begin{array}{r}-0.02 * \\
(0.01)\end{array}$ & $\begin{array}{l}-0.01 \\
(0.01)\end{array}$ & $\begin{array}{l}-0.06 * \\
(0.02)\end{array}$ & $\begin{array}{l}-0.01 \\
(0.02)\end{array}$ \\
\hline $\begin{array}{l}\text { family } \\
\text { background } W\end{array}$ & $\begin{array}{l}0.16^{\star} \\
(0.00)\end{array}$ & $\begin{array}{l}0.13^{\star} \\
(0.00)\end{array}$ & $\begin{array}{l}0.50 * \\
(0.01)\end{array}$ & $\begin{array}{l}0.40 * \\
(0.01)\end{array}$ \\
\hline$Q \times P$ & & $\begin{array}{l}-0.02 * \\
(0.00)\end{array}$ & & $\begin{array}{l}-0.06 * \\
(0.01)\end{array}$ \\
\hline
\end{tabular}

Dummies:

\begin{tabular}{|c|c|c|c|c|}
\hline Gender & Yes & Yes & Yes & Yes \\
\hline Cohort & Yes & Yes & Yes & Yes \\
\hline Birth region & Yes & Yes & Yes & Yes \\
\hline Residence region & Yes & Yes & Yes & Yes \\
\hline $\mathrm{R}^{2}$ & 0.138 & 0.141 & 0.336 & 0.344 \\
\hline
\end{tabular}

Note: robust cluster adjusted standard errors in parentheses with $\mathrm{p}<0.05=\sim, \mathrm{p}<0.01=$ *

The OLS results suggest that one additional year of parental education increases the (expected) educational attainment of children by approximately half a year, which implies strong intergenerational

12 The estimates are weighted with the population weights. 
persistence in educational attainment ${ }^{13}$. We use the estimates in the last column of the table to compute the variations in educational attainment induced over the sample period by variations in school quality and family background. Given the important and persistent differences between the developed North and the less developed South, it is instructive to perform these computations not only for the full sample but also for the two sub-samples of Northern / Central and Southern regions. We compute variations by comparing the oldest to the youngest cohort and by taking into account the interaction between school quality and family background. The data show that average educational attainment has increased by 3.03 years in the full sample, by 3.09 in the Northern / Central regions and by 2.96 in the South.

The observed variations in school quality between the oldest and the youngest cohort account for $0.516^{14}, 0.332$ and 0.763 years in the full sample and in the two sub-samples respectively. On the other hand, the observed variation in family background (both $W$ and $P$ ) account for 1.110, 1.160 and 1 year respectively. We conclude that family background has had a significantly higher impact on educational attainment than the pupil - teacher ratio, especially in the most developed areas of the country. We also notice that about half of the total variation in educational attainment is not accounted by these two variables.

Next, we turn to the two - step model [1]-[2] and examine the impact of school quality and family background on the estimated returns to education. In the estimate of equation [1] we use the following individual characteristics: gender, marital status, labor market experience and its square, dummies for the dimension of the town of residence, for part time and temporary jobs, and the number of months worked in the year. Since individual data belong to different years, we capture aggregate effects with time dummies. Finally, the endogenous selection of years of education is controlled for by adding to the regression the score computed from the ordered probit model of educational attainment. The estimated values of $\gamma$ are retrieved from the first step estimate, together with the standard errors. In the second step we estimate [2] by weighted least squares, using as weights the standard errors (see Betts [1995]). Since the data in [2] are cell averages (by region of birth, region of residence and cohort), we only retain in the estimate the cells with more than 20 observations.

Table 2 shows, for the youngest and the oldest cohort born in the North and in the South, the average values of $Q$, the pupil - teacher ratio, family background $W$, the percentage $P$ of households in the cell with primary education as the highest attainment of parents and the estimated returns to

\footnotetext{
${ }_{13}$ Computed from the fourth column of table 1 as $\frac{\partial E}{\partial W}=\left(0.40-0.06 \cdot \bar{Q} \cdot \frac{\partial P}{\partial W}\right)=0.50$ where $\frac{\partial P}{\partial W}=-0.083$ and $\bar{Q}=20.44$. The derivative of $\mathrm{P}$ with respect to $\mathrm{W}$ is the estimated coefficient of a regression of $\mathrm{P}$ on cohort, region of birth, region of residence dummies and $\mathrm{W}$.

${ }^{14}$ Computed from the fourth column of table 1 as $\Delta E=(-0.01-0.06 \cdot \bar{P}) \cdot \Delta Q=(-0.01-0.06 \cdot 0.625) \cdot(-10.88)=0.516$.
} 
education $\gamma$. Both school quality and family background have improved dramatically over time, especially among individuals born in the less developed South. The estimated returns to education are higher for the individuals born in the North. The gap between North and South has declined, however, as we move from the oldest to the youngest cohort.

Table 2. Average values of $Q, P, W$ and $\gamma$. By cohort and region of birth

\begin{tabular}{|c|c|c|c|c|}
\hline & $Q$ & $W$ & $P$ & $\gamma$ \\
\hline Oldest cohort born North & 24.07 & 5.61 & 0.735 & 0.069 \\
\hline Youngest cohort born North & 15.89 & 8.24 & 0.408 & 0.066 \\
\hline Oldest cohort born South & 30.15 & 3.92 & 0.800 & 0.046 \\
\hline Youngest cohort born North & 15.40 & 6.73 & 0.560 & 0.055 \\
\hline
\end{tabular}

The estimates of [2] are presented in Table 3. We highlight the additional contribution of each group of regressors to the explanation of the total variance of the dependent variable by starting in the table with the results from the most parsimonious specification, which only includes cohort dummies and a constant term, and by ending up with the richest specification, which corresponds to [2]. We notice that the regression which includes as explanatory variables a constant, age cohort, region of birth, region of residence dummies and their interactions produces a value of the $\mathrm{R}^{2}$ equal to 0.721 (third column in the table). As shown in the fifth column, school quality and family background, while jointly significant, do not add much to the explained variation of the estimated returns to education $\left(\mathrm{R}^{2}\right.$ equal to 0.755$)$.

We find that the coefficient associated to the pupil - teacher ratio is positive and not significantly different from zero, and that the coefficient associated to the interaction of $P$ with $Q$ is negative and statistically significant. Therefore, the relationship between the pupil - teacher ratio and the estimated returns to education varies with the average family background in the region and cohort of birth. To illustrate, we compute the elasticity of returns with respect to the pupil - teacher ratio for different values of the distribution of $P$. When $P$ is low and equal to the 10 percentile value of its distribution ( $P=0.31$ for regions/cohorts with limited illiteracy), the estimated elasticity is $0.907^{15}$, which implies that a 1 percent reduction in the pupil - teacher ratio (i.e. an improvement in school quality) reduces the returns to education by close to 1 percent. This elasticity falls to 0.244 when $P$ is equal to the 25 percentile value $(P=0.47)$ and turns negative $(-0.234)$ at the median value of $P$

${ }_{15} \frac{\partial \ln \gamma}{\partial \ln Q}=(0.0074-0.0112 \cdot P) \cdot \frac{\bar{Q}}{\bar{\gamma}}$, where $P$ is evaluated at the percentile value and the other variables are at their sample means. 
$(P=0.67)$. The negative elasticity increases further in absolute value when $P$ is at the 75 percentile value (the elasticity is -0.592 for $P=0.80$ ) and at the 90 percentile (the elasticity is -0.802 for $P=0.89)$.

The average elasticity, evaluated at the sample averages of $Q, P$ and $\gamma$, is negative and equal to -0.108 . During the sample period spanning the 6 age cohorts, the pupil - teacher ratio has declined by $42.6 \%$. Conditional on average family background, this corresponds to a $4.60 \%$ $([-42.6 \times(-0.108)])$ increase in the returns to education, from 0.058 to 0.06 .

Table 3. Second stage estimate. Dependent variable: estimated returns to education

\begin{tabular}{|c|c|c|c|c|c|}
\hline \# obs : & 161 & 161 & 161 & 161 & 161 \\
\hline Depvar: & $\gamma$ & $\gamma$ & $\gamma$ & $\gamma$ & $\gamma$ \\
\hline$W$ & & & & $\begin{array}{c}-0.0128 * \\
(0.0043)\end{array}$ & $\begin{array}{c}-0.0228^{*} \\
(0.0059)\end{array}$ \\
\hline$Q$ & & & & & $\begin{array}{c}0.0074 \\
(0.0038)\end{array}$ \\
\hline$P \times Q$ & & & & $\begin{array}{c}-0.0057 \star \\
(0.0022)\end{array}$ & $\begin{array}{c}-0.0112 \star \\
(0.0037)\end{array}$ \\
\hline
\end{tabular}

Dummies:

\begin{tabular}{|c|c|c|c|c|c|}
\hline $\begin{array}{l}\text { Cohort } \\
\text { Birth region } \\
\text { Residence reg }\end{array}$ & Yes & $\begin{array}{l}\text { Yes } \\
\text { Yes }\end{array}$ & $\begin{array}{l}\text { Yes } \\
\text { Yes } \\
\text { Yes }\end{array}$ & $\begin{array}{l}\text { Yes } \\
\text { Yes } \\
\text { Yes }\end{array}$ & $\begin{array}{l}\text { Yes } \\
\text { Yes } \\
\text { Yes }\end{array}$ \\
\hline Cohor $\times$ Res.rg & & & Yes & Yes & Yes \\
\hline Birth $\times$ Res.rg & & & Yes & Yes & Yes \\
\hline $\mathrm{R}^{2}$ & 0.348 & 0.638 & 0.721 & 0.746 & 0.755 \\
\hline
\end{tabular}

Note: standard errors in parentheses with $\mathrm{p}<0.05=\sim, \mathrm{p}<0.01=*$

Turning to the impact of family background $W$ on school returns, we find that, conditional on school quality, the returns to education are higher in the regions and cohorts of birth with lower $W$. The average elasticity of returns to changes in $W$ is equal to $-0.377^{16}$. With decreasing marginal returns to education (see Card [1999]), this negative elasticity can be explained with the fact that better parental education increases the educational attainment of children. Ceteris paribus, individuals born in regions and cohort with better family background have higher education and lower returns to education. On average, family background has improved dramatically over time and the maximum number of years of

${ }_{16} \frac{\partial \ln \gamma}{\partial \ln W}=\left(-0.0228-0.0112 \cdot \bar{Q} \cdot \frac{\partial P}{\partial W}\right) \cdot \frac{\bar{W}}{\bar{\gamma}}$, where $\frac{\partial P}{\partial W}=-0.083$ and all other variables are evaluated at their sample means. 
education attained by parents has increased by $64.2 \%$ between the oldest and the youngest cohort. Using the estimated elasticity, we find that, following this increase and conditional on school quality, the returns to education should have declined across cohorts by $24.2 \%([+64.2 \times(-0.377)])$, from 0.058 to 0.044 .

To summarize, the observed improvement in family background has had two contrasting effects. On the one hand, it has stimulated the increase in educational attainment of the younger generations. On the other hand, it has reduced the estimated returns to a year of education. Our results also point out that changes in family background have been quantitatively more important than changes in the pupil - teacher ratio for the evolution of educational attainment and of the returns to education.

Following Card [1999], we can interpret this evolution as the result of the interplay between the costs and the benefits of education. Assume that marginal benefits decline and that marginal costs increase with educational attainment. For any level of educational attainment, better school quality and improved family background are expected to improve marginal benefits and reduce marginal costs. The combination of the outward shift of marginal benefits and of the downward shift of marginal costs should have increased educational attainment, as we find, with uncertain results for the returns to education. We find that the combined effect of changes in $W$ and $Q$ have generated a reduction in the returns to education from 0.058 for the oldest cohort to 0.046 for the youngest cohort. In practice, however, estimated returns have declined only slightly, from 0.058 to 0.056 . The failure of returns to significantly decline can be explained if other intervening factors have partially or totally compensated the effects on returns of improved school quality and family background. There is a large recent empirical literature which shows that skill biased technical change is one of these factors, which has shifted relative demand in favor of better educated workers (see Katz and Autor [1999]).

Our results are consistent with the hypothesis that family background and school quality are technical substitutes in the production of human capital. As shown in the Technical Appendix, we find that a reduction in the pupil - teacher ratio by one unit reduces the contribution of a 1 percent increase in parental education to individual human capital by 0.058 percent. Since the pupil - teacher ratio for the youngest cohort is approximately 10 units lower than for the oldest cohort, our findings support the view that an improvement of public school quality, decided and administered in Italy by the central government, has had an important countervailing effect with respect to the differences induced by parental background on educational attainment and the returns to education.

\section{Conclusions}

In this paper we have investigated whether the combined significant reduction in the pupil teacher ratio and increase in parental education observed in Italy between the end of the II World War 
and the end of the 1980s have had a significant impact on the educational attainment and the labor market returns of a representative sample of Italians born between 1941 and 1970. We have found that a lower pupil - teacher ratio is positively correlated with higher educational attainment, but that the overall improvement of parental education has had an even stronger impact on attainment. Our empirical evidence also suggests that the positive impact of better school quality on educational attainment and returns to education has been particularly significant for the individuals born in regions and cohorts with poorer family background. Parental education has had asymmetric effects, positive on attainment and negative on school returns. Better school quality has also had asymmetric effects on the returns to education, positive for individuals with poor family background and negative for individuals born in regions and cohorts with relatively high parental education.

We have also shown that a better school quality, measured by a lower pupil - teacher ratio, has been a technical substitute to parental education in the production of individual human capital. When school quality and family background are substitutes, an increase of public resources invested in education can be used to reduce the differences induced by parental education.

The strong relationship between parental education and the educational attainment of the younger generations suggest that a positive shock to attainment, triggered for instance by a school reform which extends compulsory education, can have multiplicative and long lasting effects in the medium and long run, as better educated generations will give birth over time to new generations, which will enjoy a higher parental education and therefore invest in even higher educational attainment. This self - sustained mechanism is empirically stronger in Italy than a reduction in the pupil - teacher ratio.

According to our results, the significant reduction in the pupil - teacher ratio has helped most the individuals born in the less developed regions of the country, endowed with poorer parental education, and has only partially compensated the decline in the returns to education associated to higher educational attainment. A question for future research is whether the benefits associated to the observed increase in school quality have been sufficient to compensate the costs borne by the Italian taxpayer. 


\section{Technical Appendix}

Consistently with our empirical specification and with the assumption that earnings equal productivity, assume the following production function of individual human capital $H$ :

$H=e^{\gamma E}$

where $E$ is educational attainment and $\gamma$ is the return to education. The second derivative of $(\log ) H$ with respect to the pupil - teacher ratio $Q$ and $(\log )$ family background $W$ is

$\frac{\partial^{2} \ln H}{\partial Q \partial \ln W}=\left[\frac{\partial^{2} \gamma}{\partial Q \partial W} E+\frac{\partial \gamma}{\partial Q} \frac{\partial E}{\partial W}+\frac{\partial \gamma}{\partial W} \frac{\partial E}{\partial Q}+\frac{\partial^{2} E}{\partial Q \partial W} \gamma\right] W$

Based on our estimates, define

$\gamma=0.0074 \cdot Q-0.0228 \cdot W-0.0112 \cdot Q \cdot P$

$E=-0.01 \cdot Q+0.40 \cdot W-0.06 \cdot Q \cdot P$

and recall that $\frac{\partial P}{\partial W}=-0.083$

Then the first and the last term on the right hand side of [A.2] are positive and the remaining terms are negative. Evaluating the left hand side of [A.2] at sample averages, we obtain

$\frac{\partial^{2} \ln H}{\partial Q \partial \ln W}=0.058$

Since a higher pupil - teacher ratio $Q$ implies lower school quality, our evidence points to technical substitutability between family background and school quality. 


\section{References}

Behrman, J., Foster, A., Rosenzweig, M. and Vashishtha, P., [1999], Women's Schooling, Home Teaching and Economic Growth, Journal of Political Economy, 107, 6, 682-714

Betts, J., [1995], Does school quality matter? Evidence from the National Longitudinal Survey of Youth, Review of Economics and Statistics, 77, 2, 231-247.

Betts, J., [1996], Is there a link between school inputs and earnings? Fresh scrutiny of an old literature, in Burtless, G., (ed.), Does Money Matter: the effect of school resources on student achievement and adult success, Brookings Institution, Washington DC, 141-191.

Blöndal, S., S.Field and N.Girouard. 2002. Investment in Human Capital Through Post-Compulsory Education and Training. OECD Economic Department Working Paper n.333.

Brunello, G., Comi, S. e Lucifora, C., [2001], Italy, in Harmon, C., Walker, I. and Wetergaard Nielsen N., Education and Earnings in Europe, Edward Edgar, Cheltenham, United Kingdom.

Brunello, G., D.Checchi and S.Comi. [2002]. Qualità delle formazione scolastica, scelte formative ed esiti nel mercato del lavoro, Bank of Italy, mimeo.

Card, D. e Krueger, A. [1992], Does school quality matter? Returns to education and the characteristics of public schools in the United States, Journal of Political Economy, 1-39.

Card, D. e Krueger, A. [1996], Labor Market Effects of School Quality: Theory and Evidence, NBER Working Paper No. 5450. In Gary Burtless, (ed.) Does Money Matter? The Link Between Schools, Student Achievement and Adult Success, (Washington, DC:The Brookings Institution, 1996.).

Checchi, D., A.Ichino and A.Rustichini. [1999]. "More equal but less mobile ? Intergenerational mobility and inequality in Italy and in the US. Journal of Public Economics, 74: 351-393

Dearden, L., Ferri, J. e Costas Meghir [2000], The effect of school quality on educational attainment and wages, IFS working paper 22.

Dolton, P. e Vignoles, A., [1998], The impact of school quality on labor market success in the United Kingdom, mimeo, University of Newcastle upon Tyne.

Dustmann, C. [2001], Parental Background, Primary to Secondary School Transitions and Wages, IZA Discussion Paper 367

Dustmann, C., Rajah, N. e van Soest A. [2002], Class size, education and wages. CEPR discussion paper n.3397.

Ermisch, J. and Francesconi, M., [2001], Family Matters: Impact of Family Background on Educational Attainments, Economica, 68, 137-56.

Gundlach, E., Wossman, L. e Gmelin, J., [2001], The decline of schooling productivity in OECD countries, The Economic Journal, 111, C135-C147.

Hanushek, E., [1986], The Economics of Schooling: Production and Efficiency in Public Schools, The Journal of Economic Literature, 24, 1141-1177.

Hanushek, E., [2002], Publicly Provided Education, NBER Working paper \#8799, Cambridge MA

Harmon, C. e Walker, I., [2000], Selective schooling, school quality and labor market outcomes, mimeo, University College Dublin

Heckman, J. , Layne-Ferrar, A. e Petra Todd, [1997], Human capital, pricing equations with an application to estimating the effect of schooling quality on earnings, The Review of Economics and Statistics, 562-609.

OECD [2002], Education at a Glance, Paris

Sacerdote, B. [2002], The Nature and Nurture of Economic Outcomes, The American Economic Review, 
Papers and Proceedings, May, 344-348.

Strayer, W. [2002]. The return to school quality: College choice and earnings. Journal of Labor Economics 20/3: 475-503

Vella, F. and Gregory, R. [1996], Selection bias and human capital investment: estimating the rates of returns to education for young males, Labour Economics, 3, 197-219.

Wossman, L. [2000], Schooling Resources, Educational Institutions and Student Performance: the International Evidence, Kiel Working Paper 983.

Wright, R. [1999], The rate of return to private schooling, Iza Discussion paper n.92 


\section{Data Appendix}

Table A.1- Population younger than 21 by region of birth (column) and region of residence (row) Bank of Italy surveys 1993-1995-1998-2000 (weighed) - percentages

\begin{tabular}{|c|c|c|c|c|c|c|c|c|c|c|c|c|c|c|c|c|c|c|c|c|}
\hline $\begin{array}{l}\text { residence } \rightarrow \\
\text { birth } \downarrow\end{array}$ & piem & aosta & lomb & tren & vene & friu & ligu & emil & tosc & umbr & marc & lazi & abru & moli & camp & pugl & basi & cala & sici & sard \\
\hline piemonte & 94.63 & & 1.29 & & 0.15 & 0.08 & 0.30 & & 0.08 & 0.15 & 0.38 & 0.15 & 0.38 & 0.23 & 0.38 & 0.45 & 0.08 & 0.53 & 0.53 & 0.23 \\
\hline valled'aosta & & 95.00 & & & & & & & & & & 5.00 & & & & & & & & \\
\hline lombardia & 1.34 & & 90.33 & 0.17 & 0.56 & 0.06 & 1.45 & 1.79 & 0.17 & 0.11 & 0.50 & 0.50 & 0.17 & 0.34 & 0.78 & 0.61 & 0.34 & 0.11 & 0.56 & 0.11 \\
\hline trentino & & & & 99.11 & & 0.22 & & & & & & 0.67 & & & & & & & & \\
\hline veneto & 0.21 & & 0.10 & 2.06 & 94.14 & 1.75 & 0.10 & 0.51 & 0.21 & & 0.21 & 0.62 & & & & 0.10 & & & & \\
\hline friuli & & & 0.67 & & 0.45 & 98.21 & & & & & & & 0.22 & & & 0.45 & & & & \\
\hline liguria & 2.79 & & 0.82 & & & & 94.25 & 0.16 & 0.66 & & & 0.16 & 0.16 & & & 0.16 & & 0.66 & & 0.16 \\
\hline emiliaromagna & 0.08 & & 0.16 & 0.16 & 0.23 & & 0.08 & 97.97 & 0.16 & 0.16 & 0.31 & & 0.23 & & 0.08 & 0.08 & 0.08 & 0.08 & 0.16 & \\
\hline toscana & & & 0.79 & & 0.18 & & 0.61 & 0.26 & 96.40 & 1.05 & & 0.44 & & & 0.18 & & 0.09 & & & \\
\hline umbria & & & & & & & 0.15 & & 0.31 & 98.78 & 0.31 & 0.15 & 0.31 & & & & & & & \\
\hline marche & & & 0.36 & & & & & 0.61 & & 0.73 & 97.09 & 0.12 & 0.36 & & & & & & 0.73 & \\
\hline lazio & & & 0.63 & 0.08 & 0.08 & 0.08 & & 0.16 & 0.16 & 0.16 & 0.32 & 96.99 & 0.48 & & 0.40 & & & 0.16 & 0.16 & 0.16 \\
\hline abruzzi & & & 0.27 & & 0.27 & & & & 0.14 & & 0.82 & 0.55 & 97.26 & 0.55 & & & 0.14 & & & \\
\hline molise & & & & & & & & & & & & & & 97.21 & & 2.79 & & & & \\
\hline campania & 0.18 & & 0.67 & 0.07 & 0.21 & & & 0.56 & 0.39 & 0.18 & 0.35 & 0.92 & 0.07 & 0.07 & 95.62 & 0.07 & 0.32 & 0.14 & 0.14 & 0.04 \\
\hline puglia & 0.73 & & 0.73 & 0.21 & & & 0.05 & 0.21 & 0.05 & & 0.42 & 0.37 & 0.21 & 0.16 & & 96.18 & 0.63 & & & 0.05 \\
\hline basilicata & & & & 0.88 & & & & & & & & & 0.44 & & 0.44 & 0.88 & 97.37 & & & \\
\hline calabria & 0.44 & & 1.42 & 0.11 & & 0.44 & 0.22 & 0.44 & 0.66 & & & & & 0.11 & & & & 96.07 & 0.11 & \\
\hline sicilia & 0.54 & & 0.89 & & 0.05 & 0.05 & 0.20 & 0.45 & 0.15 & & 0.15 & & & & & 0.15 & & 0.15 & 97.08 & 0.15 \\
\hline sardegna & 0.33 & & & & & & 0.11 & 0.22 & & & & & & & & 0.11 & & 0.11 & 0.11 & 99.01 \\
\hline
\end{tabular}

Table A.2- Population born between 1940 and 1970 by region of birth (column) and region of residence (row) - Bank of Italy surveys 1993-1995-1998-2000 (weighed) - percentages

\begin{tabular}{|c|c|c|c|c|c|c|c|c|c|c|c|c|c|c|c|c|c|c|c|c|}
\hline $\begin{array}{l}\text { residence } \rightarrow \\
\text { birth } \downarrow\end{array}$ & piem & aosta & lomb & tren & vene & friu & ligu & emil & tosc & umbr & Marc & lazi & abru & moli & camp & pug1 & basi & cala & sici & sard \\
\hline piemonte & 88.44 & 0.11 & 4.13 & 0.11 & 0.66 & 0.16 & 2.57 & 0.50 & 0.22 & 0.07 & 0.21 & 0.87 & & 0.01 & & 0.44 & 0.08 & 0.94 & 0.36 & 0.09 \\
\hline valled'aosta & 41.64 & 47.81 & 1.33 & & & & 9.22 & & & & & & & & & & & & & \\
\hline lombardia & 1.10 & 0.03 & 91.34 & 0.21 & 1.19 & 0.24 & 1.03 & 2.44 & 0.61 & 0.08 & 0.15 & 0.29 & 0.13 & 0.01 & 0.52 & 0.18 & 0.01 & 0.25 & 0.16 & 0.02 \\
\hline trentino & 2.52 & & 3.20 & 84.76 & 6.58 & & 0.46 & 1.31 & 0.30 & & 0.05 & 0.77 & & & & & & & & 0.06 \\
\hline veneto & 2.99 & & 4.63 & 0.63 & 86.18 & 1.57 & 0.39 & 1.53 & 0.22 & 0.04 & 0.08 & 1.15 & 0.07 & & 0.01 & 0.29 & & 0.01 & 0.16 & 0.05 \\
\hline friuli & 0.98 & & 4.30 & 0.50 & 1.66 & 89.83 & 1.12 & 0.76 & 0.32 & 0.06 & 0.03 & & 0.13 & & 0.22 & & & & 0.09 & \\
\hline liguria & 2.80 & & 5.09 & 0.14 & 0.05 & 0.41 & 88.23 & 0.16 & 0.97 & & 0.57 & 0.35 & 0.13 & & 0.05 & 0.25 & & 0.13 & 0.29 & 0.38 \\
\hline emiliaromagna & 0.81 & & 3.03 & 0.22 & 0.13 & 0.05 & 0.73 & 91.94 & 0.81 & 0.26 & 0.44 & 0.83 & 0.07 & & & 0.15 & 0.03 & 0.07 & 0.25 & 0.18 \\
\hline toscana & 0.35 & & 1.99 & & 0.31 & 0.04 & 1.26 & 1.16 & 92.20 & 0.42 & 0.13 & 1.57 & & & 0.19 & & & & 0.20 & 0.19 \\
\hline umbria & 3.19 & & 1.33 & 0.07 & 0.17 & & 0.20 & 0.67 & 2.81 & 85.11 & 0.63 & 5.15 & 0.67 & & & & & & & \\
\hline marche & 0.08 & & 3.08 & 0.59 & 0.12 & 0.53 & 0.28 & 3.48 & 1.52 & 0.94 & 82.19 & 5.66 & 0.23 & 0.05 & & 0.26 & & & 0.99 & \\
\hline lazio & 0.49 & & 0.98 & 0.09 & 0.24 & 0.06 & 0.29 & 0.72 & 0.73 & 0.49 & 0.41 & 93.89 & 0.36 & 0.02 & 0.53 & 0.20 & & 0.34 & 0.13 & 0.04 \\
\hline abruzzi & 1.23 & & 1.73 & 0.28 & & 0.03 & 1.80 & 1.14 & 0.60 & 0.35 & 1.90 & 4.59 & 85.56 & 0.14 & & 0.10 & 0.46 & 0.10 & & \\
\hline molise & 2.74 & & 0.80 & 1.08 & & & & 3.13 & 0.72 & & 0.76 & 18.12 & 3.57 & 66.63 & 0.97 & 1.24 & & 0.17 & & 0.09 \\
\hline campania & 2.96 & 0.01 & 4.51 & 0.31 & 0.45 & 0.43 & 0.27 & 2.55 & 1.95 & 0.16 & 0.29 & 4.72 & 0.21 & 0.29 & 78.81 & 0.64 & 0.38 & 0.47 & 0.47 & 0.12 \\
\hline puglia & 4.95 & 0.02 & 6.16 & 0.18 & 0.84 & 0.34 & 0.26 & 1.44 & 0.48 & 0.05 & 0.49 & 2.52 & 0.34 & 0.21 & 0.20 & 80.42 & 0.27 & 0.11 & 0.62 & 0.11 \\
\hline basilicata & 7.41 & & 8.85 & 0.14 & & & 1.07 & 1.05 & 2.45 & 0.23 & 0.09 & 2.95 & 0.15 & & 1.72 & 2.25 & 71.41 & & 0.23 & \\
\hline calabria & 11.31 & 0.21 & 10.67 & 0.16 & 0.86 & 0.14 & 2.49 & 2.07 & 1.34 & 0.16 & 0.20 & 4.62 & 0.01 & 0.05 & 0.61 & 0.43 & & 64.31 & 0.25 & 0.11 \\
\hline sicilia & 4.61 & 0.08 & 6.26 & 0.12 & 0.46 & 0.31 & 1.14 & 0.77 & 1.02 & 0.10 & 0.19 & 2.01 & 0.01 & 0.05 & 0.27 & 0.23 & & 0.09 & 82.18 & 0.13 \\
\hline sardegna & 6.25 & 0.04 & 4.14 & 0.45 & 0.83 & 0.04 & 0.90 & 1.11 & 0.97 & 0.16 & 0.20 & 5.31 & 0.04 & & 0.18 & 0.19 & & & 0.40 & 78.78 \\
\hline
\end{tabular}

Table A.3 - Pupil - teacher ratios by birth cohort

\begin{tabular}{cccccc} 
cohort & Year of birth & $\begin{array}{c}\text { Relevant years for } \\
\text { school quality: } \\
\text { kindergarten }\end{array}$ & $\begin{array}{c}\text { Relevant years for } \\
\text { school quality: } \\
\text { primary school }\end{array}$ & $\begin{array}{c}\text { Relevant years for } \\
\text { school quality: } \\
\text { junior high school }\end{array}$ & $\begin{array}{c}\text { Relevant years for } \\
\text { school quality: }\end{array}$ \\
\hline $\mathbf{1}$ & $1941-45$ & $1946-48-50$ & $1948-50-52-54-56$ & $1952-54-56-58$ & $1956-58-60-62-64$ \\
$\mathbf{2}$ & $1946-50$ & $1950-52-54-56$ & $1952-54-56-58-60$ & $1958-60-62-64$ & $1960-62-64-66-68$ \\
$\mathbf{3}$ & $1951-55$ & $1954-56-58-60$ & $1958-60-62-64-66$ & $1962-64-66-68$ & $1966-68-70-72-74$ \\
$\mathbf{4}$ & $1956-60$ & $1960-62-64-66$ & $1962-64-66-68-70$ & $1968-70-72-74$ & $1970-72-74-76-78$ \\
$\mathbf{5}$ & $1961-65$ & $1964-66-68-70$ & $1968-70-72-74-76$ & $1972-74-76-78$ & $1976-78-80-82-84$ \\
$\mathbf{6}$ & $1966-70$ & $1970-72$ & $1972-74-76-78-80$ & $1978-80-82-84$ & $1980-82-84-86-88$ \\
\hline
\end{tabular}

Note: weights are enrolment rates in each type of school during the period indicated in the table. 
Table A.4 - Descriptive statistics for relevant variables sample used for the ordered probit model (32.991 observations)

$\begin{array}{lcc}\text { Variable } & \text { Mean } & \text { Standard deviation } \\ \text { Female } & 50.7 & \\ \text { Cohort: } & & \\ \text { born 1941-45 } & 15.5 & \\ \text { born 1946-50 } & 17.8 & \\ \text { born 1951-55 } & 16.2 & \\ \text { born 1956-60 } & 16.2 & \\ \text { born 1961-65 } & 16.8 \\ \text { born 1966-70 } & 17.4 & \\ \text { Residence: } & & \\ \text { North-West } & 22.3 & \\ \text { North-East } & 19.5 & \\ \text { Center } & 21.1 & 4.10 \\ \text { South } & 11.4 & 4.17 \\ \text { Islands } & 25.7 & 3.70 \\ \text { Age } & 40.64 & 4.74 \\ \text { Years of education } & 10.06 & \\ \text { Years of education of father } & 5.53 & \\ \text { Years of education of mother } & 4.79 & \\ \text { Student/teacher ratio - average } & 20.44 & \end{array}$

sample used for the two-step estimate of the returns to education (16.471 observations)

\begin{tabular}{|c|c|c|}
\hline Variable & Mean & Standard deviation \\
\hline Female & 49.0 & \\
\hline \multicolumn{3}{|l|}{ Cohort: } \\
\hline born 1941-45 & 10.7 & \\
\hline born 1946-50 & 18.2 & \\
\hline born 1951-55 & 18.5 & \\
\hline born 1956-60 & 18.3 & \\
\hline born 1961-65 & 17.8 & \\
\hline born 1966-70 & 16.5 & \\
\hline \multicolumn{3}{|l|}{ Residence: } \\
\hline North-West & 25.3 & \\
\hline North-East & 21.8 & \\
\hline Center & 21.8 & \\
\hline South & 10.6 & \\
\hline Islands & 20.5 & \\
\hline Age & 40.05 & 8.33 \\
\hline Years of education & 10.98 & 4.01 \\
\hline Years of education of father & 5.86 & 4.16 \\
\hline Years of education of mother & 5.04 & 3.62 \\
\hline Student/teacher ratio - average & 20.05 & 4.44 \\
\hline \multicolumn{3}{|l|}{ Gross annual wage: } \\
\hline 1993 survey (thousands lire) & 26893.5 & 14910.6 \\
\hline 1995 survey (thousands lire) & 28644.5 & 16313.8 \\
\hline 1998 survey (thousands lire) & 31621.0 & 19296.7 \\
\hline 2000 survey (thousands lire) & 34920.5 & 22586.5 \\
\hline Months employed per year & 11.39 & 2.01 \\
\hline Years of potential experience & 23.07 & 9.58 \\
\hline
\end{tabular}




\section{IZA Discussion Papers}

\begin{tabular}{|c|c|c|c|c|}
\hline No. & Author(s) & Title & Area & Date \\
\hline 690 & M. Hagedorn & Contracting with Private Information & 1 & $01 / 03$ \\
\hline 691 & $\begin{array}{l}\text { B. Petrongolo } \\
\text { C. A. Pissarides }\end{array}$ & Scale Effects in Markets with Search & 3 & $01 / 03$ \\
\hline 692 & $\begin{array}{l}\text { T. E. Smith } \\
\text { Y. Zenou }\end{array}$ & $\begin{array}{l}\text { Spatial Mismatch, Search Effort and Urban } \\
\text { Spatial Structure }\end{array}$ & 3 & $01 / 03$ \\
\hline 693 & $\begin{array}{l}\text { L. Gobillon } \\
\text { H. Selod } \\
\text { Y. Zenou }\end{array}$ & $\begin{array}{l}\text { Spatial Mismatch: From the Hypothesis to the } \\
\text { Theories }\end{array}$ & 3 & $01 / 03$ \\
\hline 694 & E. S. Prasad & $\begin{array}{l}\text { What Determines the Reservation Wages of } \\
\text { Unemployed Workers? New Evidence from } \\
\text { German Micro Data }\end{array}$ & 3 & $01 / 03$ \\
\hline 695 & $\begin{array}{l}\text { S. Alan } \\
\text { T. F. Crossley } \\
\text { P. Grootendorst } \\
\text { M. R. Veall }\end{array}$ & $\begin{array}{l}\text { Out-of-Pocket Prescription Drug Expenditures } \\
\text { and Public Prescription Drug Programs }\end{array}$ & 3 & $01 / 03$ \\
\hline 696 & R. Schettkat & $\begin{array}{l}\text { Institutions in the Economic Fitness Landscape: } \\
\text { What Impact Do Welfare State Institutions Have } \\
\text { on Economic Performance? }\end{array}$ & 3 & $01 / 03$ \\
\hline 697 & R. Schettkat & $\begin{array}{l}\text { Differences in US-German Time-Allocation: } \\
\text { Why Do Americans Work Longer Hours than } \\
\text { Germans? }\end{array}$ & 5 & $01 / 03$ \\
\hline 698 & $\begin{array}{l}\text { T. M. Andersen } \\
\text { J. R. Skaksen }\end{array}$ & $\begin{array}{l}\text { Product Market Integration, Comparative } \\
\text { Advantages and Labour Market Performance }\end{array}$ & 2 & $01 / 03$ \\
\hline 699 & $\begin{array}{l}\text { D. Margolis } \\
\text { V. Simonnet }\end{array}$ & $\begin{array}{l}\text { Educational Track, Networks and Labor Market } \\
\text { Outcomes }\end{array}$ & 2 & $01 / 03$ \\
\hline 700 & T. K. Bauer & $\begin{array}{l}\text { Flexible Workplace Practices and Labor } \\
\text { Productivity }\end{array}$ & 1 & $01 / 03$ \\
\hline 701 & $\begin{array}{l}\text { L. Goerke } \\
\text { J. B. Madsen }\end{array}$ & $\begin{array}{l}\text { Earnings-Related Unemployment Benefits in a } \\
\text { Unionised Economy }\end{array}$ & 3 & $01 / 03$ \\
\hline 702 & $\begin{array}{l}\text { M. Ayhan Kose } \\
\text { E. S. Prasad } \\
\text { M. E. Terrones }\end{array}$ & $\begin{array}{l}\text { How Does Globalization Affect the } \\
\text { Synchronization of Business Cycles? }\end{array}$ & 2 & $01 / 03$ \\
\hline 703 & $\begin{array}{l}\text { W. C. Horrace } \\
\text { R. L. Oaxaca }\end{array}$ & $\begin{array}{l}\text { New Wine in Old Bottles: A Sequential } \\
\text { Estimation Technique for the LPM }\end{array}$ & 6 & $01 / 03$ \\
\hline 704 & $\begin{array}{l}\text { M. Ransom } \\
\text { R. L. Oaxaca }\end{array}$ & Intrafirm Mobility and Sex Differences in Pay & 1 & $01 / 03$ \\
\hline 705 & $\begin{array}{l}\text { G. Brunello } \\
\text { D. Checchi }\end{array}$ & School Quality and Family Background in Italy & 2 & $01 / 03$ \\
\hline
\end{tabular}

An updated list of IZA Discussion Papers is available on the center's homepage www.iza.org. 